\title{
Pengaruh Model Pembelajaran Problem Based Learning TERHADAP KEMAMPUAN PEMECAHAN MASAlah MATEMATIKa SiSWA KELAS VII Di SMP NEGERI PANGKAJENE
}

\author{
The Influence of Problem Based Learning Model on Mathematical Problem \\ Solving SKILl Class VII In SMP NegERI PANGKAJENE
}

\author{
Andi Yunarni Yusri \\ Pendidikan Matematika, STKIP Andi Matappa Pangkep \\ Jl. Andi Mauraga No 70, Kabupaten Pangkajene Kepulauan, Sulawesi Selatan, Indonesia \\ Yunarniyusri@gmail.com
}

\begin{abstract}
Abstrak
Kemampuan pemecahan masalah merupakan bagian dari kurikulum matematika yang sangat penting. Model pembelajaran yang diterapkan dalam penelitian ini adalah model pembelajaran Problem Based Learning pada mata pelajaran matematika di kelas VII SMP Negeri 1 Pangkajene pada materi pecahan. Jenis penelitian yang digunakan dalam penelitian ini adalah penelitian praeksperimen. Populasi penelitian ini adalah seluruh siswa kelas VII SMP Negeri 1 Pangkajene yang terdiri dari 12 kelas dengan jumlah siswa sebanyak 439 orang. Adapun yang menjadi sampelnya adalah siswa kelas VII. Aritmatika yang diambil dengan teknik purposive sampling. Penelitian ini dilaksanakan pada semester ganjil tahun ajaran 2017/2018. Penelitian ini dilaksanakan dalam 3 kali pertemuan. Hasil penelitian secara keseluruhan menunjukkan bahwa terdapat 15 orang siswa memperoleh nilai cukup, berarti (44.1\%) siswa mendapat nilai pada rentang 55,00 - 69,99. Terdapat 17 orang siswa memperoleh nilai baik, berarti (50\%) siswa mendapat nilai pada rentang $70,00-84,99$. Dan terdapat 2 orang siswa memperoleh nilai sangat baik, berarti (5.9\%) siswa mendapat nilai pada rentang $85,00-100$. Dan nilai $F_{\text {hitung }}>F_{\text {tabel }}(5.673>4.15)$, dengan taraf signifikansi 0.23 , yang berarti bahwa terdapat pengaruh model pembelajaran problem based learning terhadap kemampuan pemecahan masalah matematika siswa kelas VII di SMP Negeri 1 Pangkajene.

Kata Kunci: Model Pembelajaran Problem Based Learning, Kemampuan Pemecahan masalah.
\end{abstract}

\begin{abstract}
Problem-solving skills are part of a very important mathematical curriculum. Learning model applied in this research is Problem Based Learning (PBL) learning model in mathematics subject in class VII SMP Negeri 1 Pangkajene on fractional material. The type of research used in this study is pre-experimental research. The population of this study is all students of class VII SMP Negeri 1 Pangkajene consisting of 12 classes with the number of students as much as 439 people. The samples are the students of class VII. Arithmetic taken by purposive sampling technique. This research was conducted in the odd semester of academic year 2017/2018. This study was conducted in 3 meetings. Overall research results show that there are 15 students who get enough value, $44.1 \%$ students get the value in the range $55.00-69.99$. There are 17 students who get good grades, $50 \%$ students get grades in the range $70.00-84.99$. And there are 2 students who get very good value, $5.9 \%$ students get the value in the range $85.00-100$. And the value Fcount> Ftable (5.673> 4.15), with significance level 0.23 , there is influence model learning problem based learning on the ability of solving problems of mathematics of grade VII students at SMP Negeri 1 Pangkajene.

Keyword: Problem Based Learning Learning Model, Problem-solving Ability.
\end{abstract}




\section{Pendahuluan}

Pendidikan merupakan salah satu faktor yang menentukan kualitas sumber daya manusia. Pemerintah melakukan berbagai upaya untuk meningkatkan mutu pendidikan melalui penyempurnaan kurikulum. Penerapan kurikulum 2013 diharapkan bisa berjalan secara optimal untuk meningkatkan kualitas pendidikan terutama pada mata pelajaran matematika.

Pelajaran matematika perlu diberikan kepada semua siswa mulai dari sekolah dasar hingga jenjang perguruan tinggi untuk membekali mereka dengan kemampuan berpikir logis, analitis, sistematis, kritis, dan kreatif, serta kemampuan bekerjasama. Ini berarti matematika memegang peranan yang sangat penting dalam berbagai dimensi kehidupan manusia, baik dalam kehidupan sehari-hari, dalam perkembangan IPTEK, maupun dalam rangka pembentukan sikap positif siswa.

Besarnya peran matematika dalam kehidupan ternyata tidak diimbangi dengan minat siswa untuk belajar matematika. Banyak kalangan menyatakan bahwa minat siswa untuk belajar matematika masih rendah. Sebagian besar siswa masih menganggap matematika sebagai mata pelajaran yang menakutkan dan membosankan. Materi matematika dirasakan sebagai beban yang harus diingat, dihafal, dan tidak dirasakan maknanya dalam kehidupan sehari-hari. Hal ini akan berdampak pada rendahnya aktivitas dan prestasi belajar matematika siswa.

Berdasarkan observasi yang dilakukan di SMP Negeri 1 Pangkajene diperoleh keterangan bahwa guru sudah berusaha melakukan perbaikan yang terbaik terhadap pelaksanaan pembelajaran untuk meningkatkan prestasi belajar matematika siswa sesuai dengan tuntutan kurikulum. Namun masih terdapat beberapa hal yang perlu ditindak lanjuti seperti kemampuan pemecahan masalah siswa masih rendah.

Kemampuan pemecahan masalah merupakan bagian dari kurikulum matematika yang sangat penting karena dalam proses pembelajaran maupun penyelesaiannya siswa dimungkinkan memperoleh pengalaman menggunakan pengetahuan dan keterampilan yang sudah dimiliki untuk diterapkan pada pemecahan masalah yang bersifat rutin. Pemecahan masalah merupakan kompetensi yang ditunjukkan siswa didalam memahami serta memilih strategi pemecahan untuk menyelesaikan suatu permasalahan.

Walaupun dianggap sangat penting, tapi kegiatan pemecahan masalah masih dianggap sebagai bahan yang sulit dalam matematika, demikian pula yang dialami siswa di SMP Negeri 1 Pangkajene, sebagian besar siswa disana merasa kesulitan jika dihadapkan dengan soal pemecahan masalah khususnya pada pembelajaran matematika. Hal ini terlihat bahwa siswa cenderung pasif dan guru selalu memberikan suatu informasi secara langsung, dalam arti siswa hanya 
menerima dan mengaplikasikan rumus tanpa tahu dari mana asalnya dan mengapa menggunakan rumus tersebut.

Kurangnya kemampuan pemecahan masalah siswa juga terlihat pada saat menghadapi soal matematika yang baru, hal tersebut nampak ketika siswa mengerjakan soal dan tidak bisa menjelaskan langkah-langkah penyelesaian soal yang ditulisnya membuat siswa menjadi sulit untuk menentukan rumus yang akan digunakan, sulit menggunakan cara-cara ataupun strategi-strategi berbeda yang akan digunakan untuk menyelesaikan masalah. Siswa hanya mampu menggunakan rumus yang ada dan terlebih lagi menghapalkan contoh-contoh soal. Dalam penyelesaian soal, siswa umumnya hanya meniru contoh soal dan ketika mengahadapi soal yang lain, siswa akan merasa kesulitan.

Fakta ini menunjukkan bahwa pengetahuan yang dimiliki oleh siswa dalam mempelajari matematika hanya sesuai dengan apa yang dijelaskan oleh guru, sehingga dalam menyelesaikan soalsoalpun hanya sebatas mengikuti contohcontoh soal yang diberikan. Hal tersebut dikarenakan kurangnya pemahaman siswa pada materi yang diajarkan oleh guru, akibatnya siswa mengalami kesulitan dalam memecahkan masalah. Kesulitan dalam memahami tersebut dapat berpengaruh pada hasil belajar siswa.

Untuk mengatasi masalah tersebut, diperlukan suatu strategi pembelajaran yang lebih variatif. Salah satu alternatif yang dapat menjadi pilihan guru dalam proses pembelajaran adalah efektivitas penggunaan model pembelajaan. Modelmodel pembelajaran hendaknya relevan dan mendukung tercapainya tujuan pembelajaran. Adapun tujuan pengajaran adalah supaya siswa dapat berfikir aktif dan diberi kesempatan untuk mencoba kemampuan di dalam berbagai kegiatan. Salah satu model pembelajaran yang dapat meningkatkan kemampuan pemecahan masalah matematika siswa adalah pembelajaran dengan model Problem Based Learning (PBL).

Pembelajaran dengan model Problem Based Learning (PBL) adalah pendekatan pengajaran yang memberikan tantangan bagi siswa untuk mencari solusi dari permasalahan dunia nyata secara individu maupun kelompok. Pembelajaran dengan model Problem Based Learning (PBL) didasarkan pada prinsip bahwa masalah dapat digunakan sebagai titik awal untuk mendapatkan ilmu baru. Masalah yang disajikan dalam pembelajaran diharapkan dapat meningkatkan motivasi siswa dalam memahami konsep yang diberikan.

Model pembelajaran Problem Based Learning (PBL) didesain dalam bentuk pembelajaran yang diawali dengan struktur masalah real yang berkaitan dengan konsep-konsep matematika yang akan diajarkan, siswa tidak hanya sekedar menerima informasi dari guru saja tetapi guru harus memotivasi dan mengarahkan siswa agar terlibat agar aktif dalam seluruh proses pembelajaran.

Oleh karena itu penulis merasa tertarik untuk mengadakan penelitian tentang 
“Pengaruh Model Pembelajaran Problem Based Learning (PBL) Terhadap Kemampuan Pemecahan Masalah Matematika Siswa Kelas VII di SMP Negeri 1 Pangkajene".

\section{Metode}

Metode yang digunakan dalam penelitian ini disebut metode kuantitatif. Jenis penelitian ini adalah penelitian praeksperimen yang dilaksanakan pada satu kelompok saja yang dinamakan kelompok eksperimen tanpa ada kelompok pembanding atau kelompok kontrol. Penelitian ini dilaksanakan di SMP Negeri 1 Pangkajene dengan responden penelitian adalah siswa kelas VII pada semester genap tahun ajaran 2017-2018.

\section{Variabel Penelitian}

a. Variabal Bebas (X): Model pembelajaran matematika berbasis Problem Based Learning (PBL).

b. Variabel Terikat (Y): kemampuan pemecahan masalah matematika

\section{Desain Penelitian}

Adapun desain dalam penelitian ini adalah causal desaign, dapat digambarkan sebagai berikut:

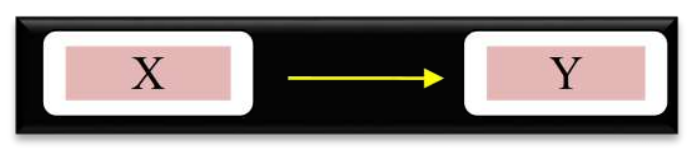

Gambar 1. Bagan Desain Penelitian.

\section{Hasil dan Pembahasan}

Pada bab ini akan disajikan hasil pengolahan data dan pembahasan hasil penelitian yang merupakan hasil dari tes hasil belajar pada pokok bahasan bilangan pecahan melalui model pembelajaran problem based learning. Hasil analisis data penelitian yang dilakukan adalah hasil analisis yang disajikan dengan menggunakan analisis deskriftif dan analisis inferensial.

\section{A. Hasil Analisis Statistik Deskriptif}

Analisis ini dimaksudkan untuk mendeskripsikan karakteristik distribusi skor dari hasil tes kemampuan pemecahan masalah yaitu hasil tes kemampuan pemecahan masalah matematika siswa kelas VII Aritmatika SMP Negeri 1 Pangkajene. Analisis deskriptif ini ditampilkan dalam bentuk rata-rata, standar deviasi, skor maksimum dan skor minimum serta ketuntasan hasil belajar siswa. Rangkuman statistik skor hasil belajar matematika siswa dan respon siswa kelas VII Arimatika SMP Negeri 1 Pangkajene pada pokok bahasan bilangan pecahan dengan menggunakan model pembelajaran problem based learning adalah sebagai berikut

a. Statistik hasil tes kemampuan pemecahan masalah matematika siswa dengan menggunakan model pembelajaran Problem Based Learning

Data hasil analisis terhadap hasil belajar matematika siswa kelas VII Arimatika SMP Negeri 1 Pangkajene pada pokok bahasan bilangan pecahan dengan menggunakan model pembelajaran problem based learning, peneliti merangkumnya seperti yang diperlihatkan pada tabel 1 berikut ini: 
Tabel 1.

Statistik Skor Hasil Tes Kemampuan Pemecahan Masalah Matematika siswa Menggunakan model

\begin{tabular}{|cc|}
\hline \multicolumn{2}{c}{ pembelajaran problem based learning } \\
\hline Statistik & Nilai Statistik \\
\hline $\mathrm{N}$ & 34 \\
\hline Rata-rata & 70.62 \\
\hline Median & 72.00 \\
\hline Modus & 61 \\
\hline Standar deviasi & 9.059 \\
\hline Variansi & 82.061 \\
\hline Rentang & 31 \\
\hline Nilai Minimum & 55 \\
\hline Nilai Maximum & 86 \\
\hline Jumlah Nilai & 2401 \\
\hline
\end{tabular}

(Sumber Peneliti: Hasil analisis data 2017)

Berdasarkan tabel 1 di atas menunjukkan bahwa, rata-rata hasil belajar siswa yang mengikuti pelajaran dengan model problem based learning pada pokok bahasan bilangan pecahan adalah 70.62 dengan modus 61 atau nilai yang paling banyak diperoleh, sedangkan nilai median menunjukkan angka 72.00 yang menunjukkan nilai tengah yang diperoleh siswa artinya nilai tengah dari jumlah sampel memperoleh nilai 70 keatas dan setengahnya lagi memperoleh nilai 70 kebawah. Standar deviasi 89.059, sedangkan variansinya adalah 82.061. Nilai maksimum yang diperoleh dari 34 siswa yang mengikuti pembelajaran dengan model pembelajaran problem based learning adalah 86, dan nilai minimumnya adalah 55, sehingga rentang data berada pada angka 31.

Selanjutnya jika data hasil belajar tersebut pada tabel 1 dikelompokkan kedalam lima kualifikasi tingkat kemampuan pemecahan masalah, maka diperoleh daftar distribusi frekuensi seperti pada tabel 2 sebagai berikut:

Tabel 2.

Deskripsi Kualifikasi Tingkat Kemampuan

Pemecahan Masalah Matematika Siswa

\begin{tabular}{|cccc|}
\hline Nilai & Kualifikasi & Frekuansi & $\begin{array}{c}\text { Persentase } \\
\text { (\%) }\end{array}$ \\
\hline $\begin{array}{c}85,00- \\
100\end{array}$ & $\begin{array}{c}\text { Sangat } \\
\text { Baik }\end{array}$ & 2 & $5.9 \%$ \\
\hline $\begin{array}{c}70,00- \\
84,99\end{array}$ & Baik & 17 & $50 \%$ \\
\hline $\begin{array}{c}55,00- \\
69,99\end{array}$ & Cukup & 15 & $44.1 \%$ \\
\hline $\begin{array}{c}40,00- \\
54,99\end{array}$ & Kurang & 0 & $0 \%$ \\
\hline $0-39,99$ & $\begin{array}{c}\text { Sangat } \\
\text { Kurang }\end{array}$ & 0 & $0 \%$ \\
\hline \multicolumn{4}{c}{ Total } \\
\hline
\end{tabular}

(Sumber Peneliti: Hasil analisis data 2017)

Berdasarkan data dari tabel 2 dapat dilihat bahwa tidak ada siswa yang memperoleh nilai sangat kurang pada rentang $0-39,99(0 \%)$, tidak ada siswa yang memperoleh nilai kurang pada rentang 40,00 - 54,99 (0\%), terdapat 15 orang siswa yang memperoleh nilai cukup pada rentang 55,00 - 69,99 (44.1\%), terdapat 17 orang siswa yang memperoleh nilai baik pada rentang 70,00 - 84,99 (50\%), dan terdapat 2 ornag siswa yang memperoleh nilai sangat baik pada rentang 85,00 - 100 (5.9\%).

Sehingga dapat dikatakan bahwa terdapat pengaruh kemampuan pemecahan masalah pada pembelajaran dengan menggunakan model pembelajaran problem based learning siswa kelas VII. Aritmatika SMPN 1 Pangkajene.

a. Hasil Respon Siswa Terhadap model pembelajran problem based learning 
Instrumen yang digunakan untuk memperoleh data respon siswa adalah angket respon siswa. Angket ini diberikan kepada siswa sesudah mengikuti kegiatan pembelajaran pada pokok bahasan bilangan pecahan dengan menggunakan model pembelajaran Problem Based Learning.

Hasil analisis data respon siswa terhadap pelaksanaan pembelajaran yang diisi oleh 20 responden, yang secara singkat ditunjukkan pada tabel berikut.

Tabel 3.

Statistik Hasil Respon Siswa Terhadap Model Pembelajran Problem Based Learning.

\begin{tabular}{|cc|}
\hline \multicolumn{1}{|c}{ Statistik } & Nilai Statistik \\
\hline $\mathrm{N}$ & 34 \\
\hline Rata-rata & 75.00 \\
\hline Median & 76.00 \\
\hline Modus & 80 \\
\hline Standar deviasi & 7.336 \\
\hline Variansi & 53.818 \\
\hline Rentang & 25 \\
\hline Nilai Minimum & 62 \\
\hline Nilai Maximum & 87 \\
\hline Jumlah Nilai & 2550 \\
\hline
\end{tabular}

(Sumber Peneliti: Hasil analisis data 2017)

Berdasarkan tabel 3 di atas menunjukkan bahwa, rata-rata respon siswa yang mengikuti pelajaran dengan menggunakan model pembelajran problem based learning adalah 75.00 dengan modus 80 atau nilai yang paling banyak diperoleh, sedangkan nilai median menunjukkan angka 76.00 yang menunjukkan nilai tengah yang diperoleh siswa artinya nilai tengah dari jumlah sampel memperoleh nilai 76.00 keatas dan setengahnya lagi memperoleh nilai 76.00 kebawah. Standar deviasi 7.336, sedangkan variansinya adalah 53.818. Nilai keaktifan maksimum yang diperoleh dari 34 siswa melalui model pembelajran problem based learning adalah 87, dan nilai minimumnya adalah 62, sehingga rentang data berada pada angka 25.

Selanjutnya jika hasil data tersebut pada tabel 4 dikelompokkan kedalam lima kategori nilai, maka diperoleh daftar distribusi frekuensi seperti pada tabel 4 sebagai berikut.

Tabel 4.

Deskripsi Persentase Hasil Respon Siswa

\begin{tabular}{|cccc|}
\hline Kepala Tabel & Kolom 1 & Kolom 2 & Kolom 3 \\
\hline $\begin{array}{c}\text { Interval Skor } \\
\begin{array}{c}0 \leq \mathrm{P} \leq \\
39,99\end{array}\end{array}$ & $\begin{array}{c}\text { Kategori } \\
\text { Kurang }\end{array}$ & Frekuensi & $\begin{array}{c}\text { Persentase } \\
(\%)\end{array}$ \\
\hline $\begin{array}{c}40 \leq \mathrm{P} \leq \\
54,99\end{array}$ & Kurang & 0 & 0 \\
\hline $\begin{array}{c}55 \leq \mathrm{P} \leq \\
64,99\end{array}$ & Cukup & 2 & 0 \\
\hline $\begin{array}{c}65 \leq \mathrm{P} \leq \\
79,99\end{array}$ & Baik & 19 & $5.9 \%$ \\
\hline
\end{tabular}

(Sumber: Hasil analisis data 2017)

Berdasarkan data dari tabel 4 dapat dilihat bahwa rata-rata respon siswa sangat baik terhadap model pembelajaran problem based learning dengan pokok bahasan bilangan pecahan karena terdapat 2 siswa yang merespon cukup pada rentang $55 \leq \mathrm{P} \leq 64,99$ (5.9\%), dan terdapat 19 siswa yang merespon baik pada rentang $65 \leq \mathrm{P} \leq 79,99$ (55.9\%), dan terdapat 13 siswa yang merespon sangat baik pada rentang $80 \leq \mathrm{P} \leq 100$ (38.2\%).

\section{B. Hasil Analisis Statistik Inferensial}

Hasil analisis statistik inferensial dimaksudkan untuk menjawab hipotesis penelitian yang telah dirumuskan. Analisis 
statistik inferensial merupakan lanjutan dari analisis deskriptif, analisis ini dilakukan dengan tahap uji normalitas terlebih dahulu yakni untuk mengetahui apakah sebaran data berasal dari populasi yang berdistribusi normal atau tidak, setelah tahap uji normalitas terpenuhi maka dapat dilakukan uji hipotesis dengan menggunakan uji regresi, hasil analisis dapat dilihat lengkap pada lampiran E.

\section{a. Uji Normalitas}

Uji normalitas dilakukan untuk mengetahui apakah sebaran data yang didapatkan berdistribusi normal atau tidak, uji ini perlu dilakukan sebagai persyaratan untuk melakukan pengujian hipotesis terhadap penelitian sebagai dasar dalam penarikan kesimpulan. Untuk mendapatkan kenormalan data, kriteria yag berlaku adalah jika p.sig. yang diperoleh $>\alpha$, maka sampel berasal dari populasi yang berdistribusi normal $\mathrm{H}_{1}$ ditolak. Jika p.sig.yang diperoleh $<\alpha$, maka sampel bukan berasal dari populasi yang berdistribusi normal Ho ditolak, dengan taraf signifikan $\alpha=0,05$.

Uji normalitas diuji dengan menggunakan program SPSS yaitu menggunakan uji kolmogorov-smirnov. Hasil analisis uji normalitas dapat dilihat pada Tabel 5 dibawah ini:

Tabel 5.

Uji Normalitas Dengan Menggunakan KolmogorovSmirnov

\begin{tabular}{lccc|}
\hline \multicolumn{4}{c}{ Kolmogorov-Smirnov } \\
\hline & Statistik & Df & Sig \\
\hline Respon siswa & 0,135 & 34 & .123 \\
\hline $\begin{array}{l}\text { Tes Kemampuan } \\
\text { Pemecahan Masalah }\end{array}$ & 0,127 & 34 & .181 \\
\hline
\end{tabular}

(Sumber Peneliti: Hasil analisis data 2017)

Dari tabel diatas dapat dilihat bahwa untuk hasil respon siswa terhadap model pembelajran problem based learning, dengan sig $=0.123>0.05$. Sedangkan data kemampuan pemecahan masalah siswa pada model pembelajaran problem based learning, dengan sig $=0.181>0.05$. Dari hasil pengujian, seluruh data signifikansi berada diatas taraf signifikansi 0.05, hal ini memberi makna bahwa seluruh data berdistribusi secara normal. Jadi pengujian normalitas terpenuhi.

\section{b. Uji Regresi linear sederhana}

Untuk menentukan persamaan regresi sederhana dapat dilakukan dengan bantuan program SPSS versi 22 pada tabel coefficients. Hasil analisis dapat dilihat pada tabel 6 dibawah ini:

Tabel 6.

Uji Regresi Dengan Menggunakan tabel coefficients

\begin{tabular}{lccc|}
\hline \multicolumn{1}{c}{ Model } & B & T & Nilai Sig \\
\hline Constant & 34.680 & 2.288 & 0,029 \\
\hline Angket & 0.479 & 2.382 & 0,023 \\
\hline
\end{tabular}

(Sumber Peneliti: Hasil analisis data 2017)

Selanjutnya melalui analisis regresi linier sederhana berdasarkan tabel coefficients, untuk membuat keputusan apakah kemampuan pemecahan masalah matematika dapat meningkat atau tidak melalui model pembelajaran problem based learning. Hasil analisis dengan menggunakan bantuan program SPSS 22 didapat nilai constan-nya (a) adalah 34.680 sedangkan koefisien garis regresinya atau respon siswanya (b)adalah 0.479. Dengan demikian persamaan regresinya bisa dituliskan sebagai berikut: 


\begin{tabular}{|c|c|}
\hline \multirow[b]{2}{*}{$*$} & $30+0.479 x$ \\
\hline & $\begin{array}{l}\text { Konstanta sebesar } 3,256 \\
\text { menyatakan bahwa jika tidak ada } \\
\text { nilai respon siswa maka nilai } \\
\text { kemampuan pemecahan masalah } \\
\text { sebesar 34.680. }\end{array}$ \\
\hline$*$ & $\begin{array}{l}\text { Koefisien regresi X sebesar } 0,479 \\
\text { menyatakan bahwa setiap } \\
\text { penambahan } 1 \text { nilai respon siswa, } \\
\text { maka nilai hasil belajar bertambah } \\
\text { sebesar } 0,479 .\end{array}$ \\
\hline & $\begin{array}{l}\text { Tabel } 7 . \\
\text { Regresi Dengan Menggunakan Tabel Model } \\
\text { Summary }\end{array}$ \\
\hline & R Square \\
\hline & $\begin{array}{l}\text { Angket dan tes } \\
\text { nampuan pemecahan } \\
\text { masalah siswa }\end{array}$ \\
\hline
\end{tabular}

(Sumber Peneliti: Hasil analisis data 2017)

Tabel diatas menjelaskan besarnya nilai korelasi/hubungan (R) yaitu sebesar 0,388 dan dijelaskan besarnya persentase pengaruh variabel bebas terhadap variabel terikat yang disebut koefisien determinasi yang merupakan hasil penguadratan $R$. dari data tersebut diperoleh koefisien determinasi (R2) sebesar 0,151 yang mengandung pengertian bahwa pengaruh variabel bebas terhadap variabel terikat adalah sebesar $15.1 \%$ sedangkan sisanya dipengaruhi oleh variabel yang lain.

1) Uji Keberartian Regresi

Dengan bantuan program SPSS versi 22 dapat ditentukan keberartian regresi pada tabel ANOVA. Hasil analisis uji regresi dapat dilihat pada tabel 8 dibawah ini.

Tabel 8.

Uji Regresi Dengan Menggunakan Tabel ANOVA

\begin{tabular}{cccc}
\hline Model & Df & F & Signifikansi \\
\hline Regression & 1 & 5.673 & 0.023
\end{tabular}

(Sumber Peneliti: Hasil analisis data 2017)

Pada bagian ini menjelaskan apakah ada pengaruh yang nyata (signifikan) antara respon siswa pada model pembelajaran problem based learning (variabel bebas) terhadap kemampuan pemecahan masalah siswa (variabel terikat). Adapun kriteria jika dilihat dari aspek nilai signifikan dan nilai $F$ sebagai berikut:

Ho: Tidak terdapat pengaruh model pembelajaran Problem Based Learning (PBL) terhadap kemampuan pemecahan masalah matematika siswa kelas VII di SMP Negeri 1 Pangkajene.

$\mathrm{H}_{1}$ : Terdapat pengaruh model pembelajaran Problem Based Learning (PBL) terhadap kemampuan pemecahan masalah matematika siswa kelas VII di SMP Negeri 1 Pangkajene.

Adapun kriteria pengujian hipotesis jika dilihat dari aspek nilai signifikan dan nilai $F$ sebagai berikut:

Jika nilai signifikan > dari nilai 0,05 maka $\mathrm{H}_{0}$ ditolak

Jika nilai signifikan < dari nilai 0,05 maka $\mathrm{H}_{1}$ diterima

Jika $F_{\text {hitung }}>\mathrm{F}_{\text {tabel }}$ maka $\mathrm{H}_{0}$ ditolak

Jika $F_{\text {hitung }}<\mathrm{F}_{\text {tabel }}$ maka $\mathrm{H}_{1}$ ditolak

Dari data di atas terlihat bahwa $F_{\text {hitung }}=$ 5.673 dengan tingkat signifikansi $0.023<$ 0.05, sedangkan $\mathrm{F}_{\text {tabel }}=4.15$, maka $\mathrm{H}_{0}$ ditolak $\mathrm{H}_{1}$ diterima, yang berarti ada pengaruh model pembelajaran Problem Based Learning (PBL) terhadap kemampuan pemecahan masalah 
matematika siswa kelas VII di SMP Negeri 1 Pangkajene.

\section{Pembahasan Hasil Penelitian}

Secara umum model pembelajran kooperatif sudah terlaksanan dengan baik, hal ini dilihat dengan baik sesuai dengan langkah-langkah Problem Based Learning, dimana pada langkah yaitu mengamati, memunculkan permasalahan, serta menumpulkan data dengan indikator materi menyelesaikan operasi penjumlahan, pengurangan, perkalian dan pembagian pada bilangan pecahan, siswa sudah dapat merumuskan suatu masalah terkait dengan fenomena yang akan diamatinya. Masalah itu dirumuskan berupa pertanyaan yang bersifat problematis, Siswa juga sudah mampu mengumpulkan informasi (data) dalam rangka menyelesaikan masalah, baik secara individu maupun kelompok.

Maksud dari tahap memahami masalah menurut Polya ialah bahwa siswa harus dapat memahami kondisi soal atau masalah yang ada pada soal tersebut. Menurutnya ciri bahwa siswa paham terhadap isi soal ialah siswa dapat mengungkapkan pertanyaaan-pertanyaan beserta jawabannya. Dari hasil tes kemampuan pemecahan masalah matematika siswa, pada tahap ini siswa sudah mampu memahami masalah, hal ini dapat dilihat berdasarkan soal nomor 1,2,3,4 dan 5 dengan indikator materi menyelesaikan operasi penjumlahan, pengurangan, perkalian dan pembagian pada bilangan pecahan, siswa sudah mampu menuliskan apa yang diketahui dan apa yang ditanyakan secara tepat.

Pada tahap kemampuan merencanakan penyelesaian masalah, siswa harus dapat memikirkan langkah-langkah apa saja yang penting dan saling menunjang untuk dapat memecahkan masalah yang dihadapinya. Pada tahap ini hanya sebagian siswa yang mampu merencanakan penyelesaian dengan membuat gambar (rumus) berdasarkan masalah secara tepat, karena masih ada beberapa siswa yang tidak merencanakan penyelesaian masalah sama sekali (tidak menuliskan rumus).

Pada tahap menyelesaikan masalah sesuai rencana ini siswa harus dapat membentuk sistematika soal yang lebih baku, dalam arti rumus-rumus yang akan digunakan sudah merupakan rumus yang siap untuk digunakan sesuai apa yang digunakan dalam soal, kemudian siswa mulai memasukkan data-data hingga menjurus kerencana pemecahannya, setelah itu baru siswa melaksanakan langkah-langkah rencana sehingga yang akan diharapkan dari soal dapat diselesaikan. Untuk kemampuan menyelesaikan masalah pada soal nomor 1, 2, 4, dan 5 sebagian besar siswa sudah mampu melaksanakan rencana dengan menuliskan jawaban dengan lengkap dan benar, tetapi pada soal nomor 3 hanya sebagian siswa yang dapat melaksanakan rencana dengan menuliskan jawaban tetapi jawaban salah atau hanya sebagian besar jawaban benar.

Pada tahap memeriksa kembali diharapkan dari keterampilan siswa dalam 
memecahkan masalah untuk tahap ini adalah siswa harus berusaha mengecek ulang dan menelaah kembali dengan teliti setiap langkah pemecahan yang dilakukan. Pada tahap ini siswa sudah mmapu menafsirkan hasil yag diperoleh dengan membuat kesimpula secara tepat.

Hal ini berkaitan dengan teori konstruktivisme yang berarti siswa dapat berpikir untuk menyelesaikan masalah, mencari ide dan membuat keputusan. Siswa akan lebih paham karena mereka terlibat langsung dalam membina pengetahuan baru, mereka akan lebih paham dan mampu mengaplikasikannya.

Jika dilihat dari kualifikasi kemampuan pemecahan masalah siswa, bahwa tidak ada siswa yang memperoleh nilai sangat kurang, yang berarti (0\%) siswa mendapat nilai dibawah 0 - 39,99. Tidak ada siswa yang memperoleh nilai kurang, yang berarti (0\%) siswa mendapat nilai pada rentang 40,00 - 54,99. Terdapat 15 orang siswa yang memperoleh nilai cukup, yang berarti (44.1\%) siswa mendapat nilai pada rentang 55,00 - 69,99. Terdapat 17 orang siswa yang memperoleh nilai baik, yang berarti (50\%) siswa mendapat nilai pada rentang 70,00 - 84,99. Dan terdapat 2 orang siswa yang memperoleh nilai sangat baik, yang berarti (5.9\%) siswa mendapat nilai pada rentang 85,00- 100 .

Sedangkan respon siswa terhadap model pembelajaran Problem Based Learning dengan pokok bahasan bilangan pecahan dalam kategori baik, karena terdapat 2 siswa yang merespon cukup, yang berarti $5.9 \%$ nilai siswa berada pada rentang $55 \leq \mathrm{P} \leq$ 64,99, dan terdapat 19 siswa yang merespon baik, yang berarti $55.9 \%$ nilai siswa berada pada rentang 65 $\leq \mathrm{P} \leq$ 79,99, dan terdapat 13 siswa merespon sangat baik, berarti $38.2 \%$ nilai siswa berada pada rentang $80 \leq P \leq 100$.

Sehingga dapat dikatakan bahwa adanya pengaruh kemampuan pemecahan masalah matematika siswa pada pembelajaran dengan menggunakan model pembelajaran Problem Based Learning siswa kelas VII. Aritmatika SMP Negeri 1 Pangkajene. Hal ini sejalan dengan penelitian yang dilakukan oleh Shinta Sari dkk (2014) dengan judul pengaruh pendekatan pembelajaran berbasis masalah terhadap kemampuan pemecahan masalah matematika siswa kelas VIII SMPN 1 Padang tahun pelajaran 2013/2014, dari hasil penelitiannya diperoleh kesimpulan yaitu peningkatan kemampuan pemecahan masalah matematika siswa yang diajar dengan pendekatan Problem Based Learning lebih tinggi dari pada siswa yang diajar secara konvensional.

Dari hasil penelitian dan hasil dari analisis diperoleh nilai $F_{\text {hitung }}>F_{\text {tabel }}(5.673$ $>4,15)$, dengan taraf signifikansi 0.023, terlihat bahwa $F_{\text {hitung }}=5.673$ dengan tingkat signifikansi $0.023<0.05$, sedangkan $\mathrm{F}_{\text {tabel }}=4.15$, maka $\mathrm{H}_{0}$ ditolak $\mathrm{H}_{1}$ diterima, yang berarti ada pengaruh model pembelajaran Problem Based Learning (PBL) terhadap kemampuan pemecahan masalah matematika siswa kelas VII di SMP Negeri 1 Pangkajene. 
Seperti yang telah diuraikan dalam analisis deskriptif dan analisis inferensial nilai serta sikap siswa mengalami peningkatan yang cukup baik sehingga dapat disimpulkan bahwa adanya pengaruh yang positif dan signifikan antara kemampuan pemecahan masalah matematika akibat penerapan model pembelajaran Problem Based Learning (PBL) siswa kelas VII SMP Negeri 1 pangkajene.

\section{Penutup}

Berdasarkan hasil penelitian yang diperoleh maka dapat disimpulkan bahwa, terdapat pengaruh setelah diterapkan model pembelajaran Problem Based Learning (PBL) terhadap kemampuan pemecahan masalah matematika siswa. Hal ini terjadi karena dalam penerapan model pembelajaran Problem Based Learning (PBL) siswa lebih memahami masalah, merencanakan masalah, menyelesaikan masalah sesuai rencana, serta melakukan pengecekan kembali atau menafsirkan solusi. Dan didukung nilai $F_{\text {hitung }}>F_{\text {tabel }}(5.673>4,15)$, dengan taraf signifikansi 0,05, sedangkan nilai koefisien regresi $Y^{\prime}=34.680+0,479 X$, hal ini menunjukan bahwa adanya pengaruh yang positif dan signifikan antara kemampuan pemecahan masalah matematika akibat penerapan model pembelajaran Problem Based Learning (PBL) siswa kelas VII SMP Negeri 1 Pangkajene.

\section{DAFTAR PUSTAKa}

Ali Hamzah, Muhlisrarini, 2014, Perencanaan Dan Strategi Pembelajaran Matematika, PT Raja Grapindo Persada, Jakarta

Bagus Murdiono, 2015, Perbandingan Model Pembelajaran Problem Based Learning Dan Model Pembelajaran Kooperatif Tipe STAD Terhadap Hasil Belajar Matematika Siswa Kelas VII Mts Baru-Baru Tanga, Skripsi, Jurusan Pendidikan Matematika, Sekolah Tinggi Kegururan Dan Ilmu Pendidikan, Pangkep

Diyah Hoiriyah, 2015, Peningkatan Kemampuan Pemecahan Masalah Matematika Dan Self-Efficacy Siswa Melalui Pembelajaran Berbasis Masalah Di MAN 1 Padangsidimpuan, Jurnal, Vol.III No 1

Evimaz Yulianti Dkk, 2016, Pengaruh Model Problem Basd Learning (PBL) Terhadap Kemampuan Pemecahan Masalah Matematika Siswa Kelas X SMA Negeri 2 Labuklingg, Jurnal, http://mahasiswa.mipastkipllg.com/re pository/

Artikel\%20Evimaz\%20Yulianti.pdf (diunduh tanggal 3 Desember 2016).

Ika Susilawati. 2012. Perbandingan Peningkatan Kemampuan Berpikir Kritis Siswa Didasarkan pada Model STAD dan PBL pada Mata Pelajaran IPS-Ekonomi Siswa Kelas V III SMP Raden Fatah Batu. SMP Raden Fatah Batu. hhttp://fe.um.ac.id/wpcontent/uploads/2012/08/KaryaIlmiah3.pdf (di unduh tanggal 17 November 2016)

Junita Amalia Dkk, 2014, Pengaruh Penerapan Pembelajaran Berbasis Masalah Terhadap Kemampuan Pemecahan Masalah Siswa Kelas VIII 
Smpn 8 Padang, jurnal, pendidikan matematika, Vol 3 No 2, Part 1 : Hal 38-43

Kosasih (Ed.), 2015, Strategi Belajar Dan Pembelajaran Implementasi Kurikulum 2013, Yrama Widiya, Bandung

Nur fatmawati Tangio, 2015, Deskripsi Kemampuan Pemecahan Masalah Matematika Pada Materi Soal Cerita Penjumlahan Dan Pengurangan Bilangan Bulat Dikelas VII SMP Negeri 1 Tapa, Jurnal, http://kim.ung.ac.id/index.php/KIMF MIPA/article/download/12392/12260 (di unduh tanggal 16 November 2016).

Putera Jaya Dkk (Ed.), 2016, Pedoman Penyusunan Proposal Penelitian Dan Skripsi, Sekolah Tinggi keguruan Dan IImu Pendidikan (STKIP) Andi Matappa Pangkep

Rostina Sundaya (Ed.),2015, Media Dan Alat Peraga Dalam Pembelajaran Matematika, Alfabeta, Bandung

Saenal, 2015, Penerapan Model Pembelajaran Problem Based Instruction (PBI) Pada Pelajaran Matematika Peserta Didik Kelas VII SMP Negeri 1 Tondong Tallasa, Skripsi, Jurusan Pendidikan Matematika, Sekolah Tinggi Kegururan Dan IImu Pendidikan, Pangkep.

Shinta Sari dkk, 2014, Pengaruh Pendekatan Pembelajaran Berbasis Masalah Terhadap Kemampuan Pemecahan Masalah Matematika Siswa Kelas VIII SMP Negeri 1 Padang Tahun Pelajaran 2013/2014, Jurnal, pendidikan matematika, part 1 , hlm 54-59

http://ejournal.unp.ac.id/students/ind ex.php/pmat/article/viewFile/1190/88 $\underline{2}$
Siti Mawaddah, Hana Anisah, 2015, kemampuan pemecahan masalah matematis siswa pada pembelajaran matematika dengan menggunakan model pembelajaran generative (generative learning) di SMP, Jurnal, pendidikan matematika, volume 3 , nomor 2, hlm 166-175 https://www.google.com/search?q=+ Siti+Mawaddah\%2C+Hana+Anisah\%2C +2015\%2C+kemampuan+pemecahan+ masalah+matematis+siswa+pada+pe mbelajaran+matematika+dengan+me nggunakan+model+pembelajaran+gen erative+\%28generative+learning\%29+ di+SMP\%2C+Jurnal\%2C+pendidikan+ matematika\%2C+volume+3\%2C+nom or+2\%2C+hlm+166-175+\&ie=utf-

8\&oe=utf-8\&client=firefox-b

Sugiyono (Ed.), 2015, Metode Penelitian Pendidikan, Alfabeta, Bandung

Suyadi (Ed.), 2015, Strategi Pembelajaran Pendidikan Karakter, Remaja Rosdakarya, Yogyakarta

Yusuf Hartono (Ed.), 2014, Matematika Strategi Pemecahan Masalah, Graha Ilmu, Palembang

\section{Riwayat Hidup PenUlis}

\section{Andi Yunarni Yusri, S.Pd. M.Pd.}

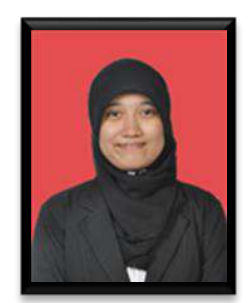

Lahir di Ujung Pandang, 16 Juni 1990. Dosen tetap yayasan di STKIP Andi Matappa, Kabupaten Pangkep, SUL-SEL. Menjabat sebagai Sekretaris Pogram Studi Pendidikan Matematika di STKIP Andi Matappa. Mengambil jurusan International Class Program of Mathematics pada jenjang S1 di Universitas Negeri Makassar dan lulus pada tahun 2012; pada tahun 2013 melanjutkan pendidikan S2 bidang Pendidikan Matematika di Universitas Negeri Makassar dan lulus pada tahun 2015. 